\title{
PERLAKUAN AKUNTANSI UNTUK SISA BAHAN BAKU (STUDI KASUS PTPN I UNIT PKS TANJUNG SEUMANTOH ACEH TAMIANG)
}

\author{
Muhammad Nurdiansyah ${ }^{1}$, Cut Afrianandra ${ }^{* 2}$ \\ ${ }^{1,2}$ Program Studi Akuntansi Fakultas Ekonomi Universitas Syiah Kuala \\ e-mail: mhdnurdian@gmail.com ${ }^{1}$, afrianandra_cut@unsyiah.ac.id ${ }^{* 2}$
}

\section{* Corresponding Author}

\begin{abstract}
The purpose of this research is to know how the accounting treatment for the scrap materials at PTPN 1 unit PKS Tanjung Seumantoh Aceh Tamiang. The scrap material from the palm oil production process at PTPN 1 unit PKS Tanjung Seumantoh Aceh Tamiang are in the form of palm shells and fiber. The type of this research is qualitative research with descriptive analysis method. The result of shows that the scrap material for palm kernel shells was recognized as other income and presented in the company's income statement, while fiber was used as boiler fuel as well as a reduction in manufacturing overhead costs.
\end{abstract}

Keywords: Accounting treatment, scrap materials

\section{Pendahuluan}

Dunia perekonomian terus mengalami perkembangan dan pertumbuhan dengan sangat cepatnya. Hal ini ditandai dengan perkembangan teknologi dan informasi secara global yang mengakibatkan persaingan dunia bisnis semakin ketat dan kompleks. Pada lingkup perkembangan ekonomi, sektor industri memiliki peranan yang sangat penting karena perusahaan industri atau perusahaan manufaktur menyediakan berbagai kebutuhan masyarakat, serta dapat menyerap banyak tenaga kerja guna meningkatkan taraf hidup masyarakat (Ellystina, 2004).

Suatu perusahaan manufaktur, ada kalanya bahan baku yang sama dapat menghasilkan produk lebih dari satu jenis produk bahkan dapat menghasilkan produk yang berbeda, misalnya bahan baku kayu dapat digunakan membuat meja dan kursi. Jenis produk ini disebut dengan produk bersama, yaitu produk yang secara sengaja dihasilkan melalui produk inti melalui serangkaian proses produksi secara simultan (Carter, 2009).

Lebih lanjut, mengenai produk bersama yang dihasilkan oleh perusahaan menghasilakan sisa bahan baku yang dapat digunakan untuk menambah pendapatan perusahaan. Serangkaian proses produksi tersebut menyebabkan suatu kondisi dimana perusahaan hanya memproduksi satu jenis produk.
Namun bisa saja dari proses produksi tersebut dapat menghasilkan produk baru yang sebenarnya muncul akibat adanya serangkaian proses yang tejadi secara simultan.

Menurut Celily \& Michael (2011:65) produk sampingan dikategorikan menjadi dua macam, yaitu: produk yang tidak mempunyai nilai ekonomis, sehingga tidak dapat dijual. produk ini dikenal dengan istilah limbah produksi (waste), dan produk yang mempunyai nilai ekonomis berapapun besarnya; apakah menjadi bahan baku produk lain, atau dijual. Produk ini dapat dikategorikan sebagai produk sampingan (by product).

PTPN I unit PKS Tanjung Seumantoh Aceh Tamiang adalah salah satu perusahaan industri yang memproduksi minyak kelapa sawit. Dalam proses pengolahan buah kelapa sawit menjadi CPO (Crude Plam oil) terjadi pelepasan kulit buah dan daging buah, yang dimana dalam proses produksi tersebut menghasilkan sisa bahan baku berupa fibre dan cangkang sawit.

Dalam proses pengolahan bahan baku menjadi produk jadi, tidak dapat dihindarkan dari kerugiankerugian tertentu atau pengurangan-pengurangan biaya produksi yang dikorbankan dari sisa bahan baku yang tidak dapat digunakan lagi, sehingga untuk memperkecil kerugian tersebut perusahaan dapat mengolah kembali sisa bahan baku tersebut menjadi 
produk sampingan untuk memberikan tambahan pendapatan bagi perusahaan.

Berdasarkan pemaparan dari latar belakang diatas, penulis ingin melakukan penelitian mengenai bagaimana perlakuan akuntansi untuk sisa bahan baku pada PTPN I unit PKS Tanjung Seumantoh Aceh Tamiang.

\section{Tinjauan Pustaka dan Kerangka Pemikiran Aset/Barang Milik Daerah}

\section{Akuntansi biaya}

Akuntansi biaya adalah bagian dari ilmu akuntansi yang mempelajari prosedur pencatatan, pengukuran serta pelaporan informasi biaya yang digunakan dalam proses produksi. Akuntansi biaya juga membahas mengenai bagaimana penentuan harga pokok dari suatu produk yang dihasilkan perusahaan, serta untuk persediaan produk yang akan dijual (Bustami \& Nurlela, 2013:4).

\section{Peran Akuntansi Biaya}

Akuntansi biaya adalah alat yang dibutuhkan oleh manajemen dalam menyusun aktivitas perencanaan dan pengendalian, mengevaluasi kualitas, meningkatkan efisiensi serta membuat keputusankeputusan yang bersifat rutin maupun yang bersifat strategis. Bustami dan Nurlela (2013:4) menjelaskan bahwa akuntansi biaya dapat membantu manajemen dalam menyelesaikan suatu permasalahan seperti (1) Penyusunan anggaran dan pelaksanaan anggaran operasi perusahaan; (2) Penetapan metode dan prosedur perhitungan biaya, pengendalian biaya, pembebanan biaya yang akurat, dan perbaikan mutu yang berkesinambungan; (3) Penentuan nilai persediaan yang digunakan untuk kalkulasi biaya dan penetapan harga, evaluasi terhadap produk, evaluasi kinerja departemen atau divisi, pemeriksaan persediaan secara fisik; (4) Menghitung biaya dan laba perusahaan untuk satu periode akuntansi, tahunan atau periode yang lebih singkat; (5) Memilih sistem dan prosedur dari alternatif yang terbaik, guna dapat menaikkan pendapatan maupun menurunkan biaya.

\section{Akuntansi Sisa Bahan}

Menurut Sujarweni (2015:39) terdapat beberapa permasalahan mengenai akuntansi biaya bahan baku, yaitu perlakuan akuntansi terhadap biaya bahan baku yang berkaitan dengan sisa bahan baku (scrap material), produk cacat (defective goods) dan produk rusak (spoiled goods)."

Sisa bahan baku merupakan bahan baku yang tersisa dari serangkaian proses produksi yang tidak dapat digunakan lagi sesuai dengan apa yang ditujukan diawal. Namun bahan sisa tersebut masih bisa digunakan pada proses produksi dengan tujuan lain (Halim, 2012:60). Sisa bahan ini dapat terjadi dikarenakan beberapa faktor, yakni: sebuah proses dimana terjadi lempengan bahan yang tidak dapat digunakan sebagai bahan baku pada produk utama, bahan yang rusak dan tidak dapat dikembalikan kepada pemasok atau bahan yang rusak dari kesalahan pekerja atau kerusakan pada mesin.

\section{Perlakuan Akuntansi Sisa Bahan}

Menurut Sujarweni (2015:39) perlakuan akuntansi terhadap sisa bahan, yakni:

1. Hasil dari penjualaan sisa bahan digunakan sebagai pengurangan biaya bahan baku yang dipakai dalam pesanan tersebut. Apabila terdapat sisa bahan dari proses pengolahan pesanan tertentu, maka hasil dari penjualan sisa bahan ini dapat teridentifikasikan dengan pesanan tersebut. Jurnal yang dapat dibuat pada saat penjualan sisa bahan adalah:

$$
\begin{aligned}
& \text { Dr. Kas/Pitang Dagang } \\
& \text { Cr. Barang Dalam Proses }- \\
& \quad \text { Biaya Bahan Baku }
\end{aligned}
$$

$\mathrm{XXX}$

Hasil dari penjualan sisa bahan juga dapat dicatat pada kartu harga pokok pesanan dalam kolom "Biaya Bahan Baku" untuk pengurang biaya bahan baku pesanan tersebut.

2. Hasil dari penjualan sisa bahan juga dapat digunakan sebagai pengurang biaya overhead pabrik. Jika sisa bahan tidak dapat diidentifikasi dengan pesanan tertentu, dan merupakan hal yang biasa terjadi dalam proses produksi, maka hasil penjualan tersebut bisa digunakan sebagai pengurang biaya overhead pabrik. Jurnal yang di catat pada saat penjualan sisa bahan adalah:

\footnotetext{
Dr.Kas/Piutang Dagang $\quad \mathrm{xxx}$

Cr. Biaya Overhead Pabrik Sesungguhnya xxx
} 
3. Hasil dari penjualan sisa bahan selain digunakan untuk pengurangan biaya bahan baku dan overhead pabrik juga dapat digunakan sebagai pendapatan dari luar usaha (other income). Pada dua perlakuan sisa bahan sebelumnya, hasil dari penjualan digunakan sebagai pengurang biaya produksi. Selain sebagai pengurangan dari biaya prosukdi, penjualan dari sisa bahan juga dapat digunakan sebagai pengahsilan dari luar usaha. Jurnal dari penjualan sisa bahan tersebut adalah:

\section{Dr. Kas/Piutang Dagang xxx \\ Cr. Hasil Penjualan Sisa Bahan $\mathrm{xxx}$}

Hasil penjualan sisa bahan disajikan dalam laporan laba rugi pada kelompok pendapatan/pengahsilan diluar usaha (other income).

\section{Penelitian terdahulu}

Susetya (2001) dalam penelitiannya mengenai analisa pengambilan keputusan penggunaan sisa bahan dan pengaruhnya terhadap harga pokok produksi pada PT. Roy Valentino Semarang menunjukkan bahwa perusahaan yang melakukan proses lebih lanjut terhadap sisa bahan baku menjadi produk sampingan dapat menjadi efisiensi pengurang terhadap biaya bahan baku yang dipakai.

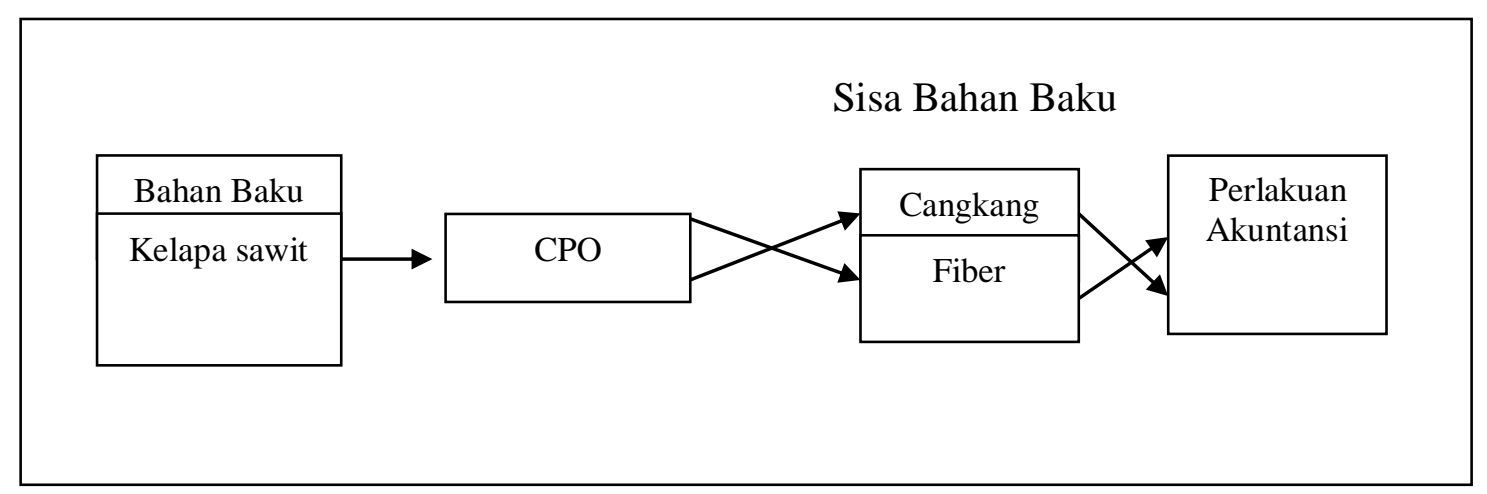

Gambar 1. Skema Kerangka Pemikiran

Berdasarkan skema kerangka pemikiran diatas dapat dilihat bahwa bahan baku utama adalah kelapa sawit. Bahan baku tersebut menghasilkan produk utama berupa CPO. Pada saat butiran biji kelapa sawit diolah menjadi CPO, dalam proses produksi tersebut terjadi pelepasan kulit buah dan daging buah kelapa sawit, sehinggga dari sisa produksi tersebut menghasilkan material berupa fibre dan cangkang yang merupakan sisa bahan baku. Dari sisa bahan baku tersebut penulis ingin melihat bagaimana perlakuan akuntansi yang digunakan pada perusahaan tersebut.

\section{Metodologi Penelitia \\ Desaian penelitian}

Penelitian ini dikategorikan sebagai penelitian kualitatif berdasarkan jenis datanya. Tujuan studi dalam penelitian ini adalah untuk menganalisis perlakuan akuntansi untuk sisa bahan baku pada PTPN I unit PKS Tanjung Seumantoh Aceh Tamiang. Tingkat intervensi yang digunakan adalah minimal, situasi studi tidak diatur, unit analisis yaitu PTPN 1 unit PKS Tanjung Seumantoh Aceh Tamiang dan horizon waktu yang digunakan adalah cross-sectional.

\section{Sumber dan Teknik Pengumpulan Data Sumber Data}

Dalam penelitian ini sumber data yng digunakan yaitu terdiri dari :

1. Data Primer

Data primer dalam penelitian ini meliputi laporan hasil produksi fibre dan cangkang pada tahun 2016, 2017 dan 2018 PTPN I unit PKS Tanjung Seumantoh Aceh Tamiang.

2. Data sekunder

Data sekunder dalam penelitian ini meliputi bahan-bahan kepustakaan sebagai referensi seperti buku- buku yang berhubungan dengan perlakuan akuntansi untuk sisa bahan baku, internet, karya ilmiah seperti skripsi dan 
informasi lainnya yang berhubunngan dengan penelitian.

\section{Teknik pengumpulan Data}

Pada penelitian ini teknik pengumpulan yang digunakan adalah observasi, dokumentasi, dan studi kepustakaan.

\section{Metode Analisis Data}

Dapal penelitian ini metode analisis yang digunakan adalah metode analisis deskriptif. Didalam metode ini hipotesis tidak dibutuhkan, namun untuk mempermudah peneliti dalam melakukan penelitian maka dibutuhkan kerangka pemikiran. Secara sistematis tahapan analisis datanya dapat dicermati dalam penjelasan berikut:

1. Tahap pertama proses penelitian adalah dengan menelaah data tentang proses produksi yang terdiri dari beberapa sumber. Data ini didapat dari hasil pengamatan yang sudah dicatat pada saat pengamatan langsung di PTPN I unit PKS Tanjung Seumantoh Aceh Tamiang, dokumen resmi, dan data lainnya. Keragaman sumber data ini dapat mengindikasikan bahwa data penelitian yang harus diamati begitu beragam dan bervariasi.

2. Kemudian data yang telah didapat, dipelajari dan ditelaah dan kemudian diabstaksi. Abstaksi merupakan usaha untuk membuat rangkuman inti, proses dan pertanyaan-pertanyaan yang tetap dalam lingkup penelitian. Proses abstraksi yang dilakukan yaitu mengenai Perlakuan Akuntansi Untuk Sisa Bahan Baku.

3. Langkah selanjutnya, menyusun data dalam satuan untuk menentukan karakteristik dari Perlakuan Akuntansi untuk Sisa Bahan Baku.

4. Tahap terakhir yang dilakukan adalah memeriksa keabsahan data. Salah satu faktor keabsahan data yang digunakan dapat dilihat dari kadar keilmiahan hasil pemeriksaan sebuah data. Maka dari itu, keabsahan data sangat penting untuk di lihat dari kesesuaian data yang telah didapat.

\section{Hasil penelitian dan pembahasan \\ Gambaran umum objek penelitian}

PT. Perkebunan Nusantara I (Persero) adalah satu-satunya BUMN pada sektor perkebunan yang ada di Provinsi Aceh. Perusahaan ini terbentuk dari hasil konsolidasi BUMN Perkebunan yang didasari oleh PP No. 6 Tahun 1996. Pengukuhan perusahaan dilakukan sesuai dengan Akta Pendirian No. 34 tanggal 11 Maret 1996 oleh Notaris Harun Kamil, SH di Jakarta. Dalam melakukan serangkaian aktivitas bisnisnya, perusahaan ini memiliki sebuah pabrik yang telah beroperasi jauh sebelum dilakukannya konsolidasi yakni Pabrik Kelapa Sawit (PKS) Tanjung Seumantoh.

Pabrik Kelapa Sawit (PKS) Tanjung Seumantoh didirikan pada tahun 1978. Terletak di Kecamatan Karang Baru, Kabupaten Aceh Taming yang berjarak $\pm 12 \mathrm{Km}$ dari Kota Kuala Simpang dan $\pm 25 \mathrm{Km}$ dari Kantor Pusat PTP. Nusantara I. Pabrik ini mulai dioperasikan pada bulan April 1980 dengan kapasitas olah sebanyak 30 ton TBS/Jam. Adanya peningkatan produksi TBS dari tahun ke tahun, maka pada tahun 1984 PKS Tanjung Seumantoh menambah beberapa instalasi guna menaikan kapasitas olah mereka dari 30 ton TBS/Jam meningkat menjadi 45 ton TBS/Jam. Peningkatan juga dilakukan dalan bentuk pembebasan tanah dengan luas perkebunan secara keseluruhan $3.500 \mathrm{Ha}$ yang ditujukan untuk keperluan pengembangan pengelolaan yang lebih besar. Adapun sumber bahan baku pengelolaan yang digunakan oleh perusahaan berasal dari kebun perusahaan dan kebun petani.

\section{Hasil penelitian}

PTPN I unit PKS Tanjung Seumantoh Aceh Tamiang merupakan perusahaan manfaktur yang memproduksi minyak kelapa sawit, yang memiliki sisa bahan baku berupa Cangkang Sawit dan Fibre. PKS Tanjung Seumantoh Aceh Tamiang adalah salah satu unit produksi dari PT Perkebunan Nusantara I (persero).

Dalam proses memproduksi bahan baku menjadi produk jadi, adakalanya bahan baku tersebut tidak semuanya menjadi produk jadi dan tidak dapat dihindarkan dari kerugian-kerugian tertentu atau pengurangan-pengurangan biaya produksi yang dikorbankan dari sisa bahan yang tidak dapat dipakai lagi, maka untuk memperkecil kerugian tersebut perusahaan dapat mengolah kembali ampas dari kelapa sawit tersebut menjadi suatu produk sampingan untuk menambah pendapatan perusahaan. Berikut 
merupakan data produk sampingan cangkang sawit dan fibre pada tahun 2016, 2017 dan 2018.

Tabel 4.1

Produk sampingan Cangkang Sawit

\begin{tabular}{|c|c|c|}
\hline \multirow{2}{*}{ No } & \multirow{2}{*}{ Tahun } & Total \\
\cline { 3 - 3 } & & Cangkang Sawit \\
\hline 1. & 2016 & $\operatorname{Rp~3,980,907,300}$ \\
\hline 2. & 2017 & $\operatorname{Rp~2,911,282,410}$ \\
\hline 3. & 2018 & $\operatorname{Rp~2,328,001,120}$ \\
\hline
\end{tabular}

Sumber: PKS Tanjung Seumantoh Aceh Tamiang

Pada tabel 4.1, pendapatan lain-lain yang diperoleh dari total penjualan cangkang sawit di PTPN I unit PKS Tanjung Seumantoh Aceh Tamiang pada tahun 2016 sebesar Rp 3.980.907.300, Pada tahun 2017 memperoleh penjualan cangkang sawit Rp 2,911,282,410 dan pada tahun 2018 memperoleh penjualan $\operatorname{Rp} 2,328,001,120$.

Tabel 4.2

Produk sampingan fibre

\begin{tabular}{|c|c|c|}
\hline \multirow{2}{*}{ No } & \multirow{2}{*}{ Tahun } & Total \\
\cline { 3 - 3 } & & Fibre \\
\hline 1. & 2016 & $80,220,560 \mathrm{Kg}$ \\
\hline 2. & 2017 & $121,110,560 \mathrm{Kg}$ \\
\hline 3. & 2018 & $134,527,722 \mathrm{Kg}$ \\
\hline
\end{tabular}

Sumber: PKS Tanjung Seumantoh Aceh Tamiang

Pada tabel 4.2, total produksi fibre di PTPN I unit Tanjung Seumantoh Aceh Tamiang pada tahun 2016 sebanyak $80.220 .560 \mathrm{~kg}$, pada tahun 2017 total produksi fibre sebanyak $121,110,560 \mathrm{Kg}$ dan pada tahun 2018 total produksi fibre sebanyak 134,527,722 $\mathrm{Kg}$.

\section{Pembahasan}

Sisa bahan baku merupakan sisa dari proses produksi bahan baku yang tidak bisa digunakan lagi untuk tujuan semula, namun masih dapat digunakan pada proses produksi untuk tujuan lain (Halim, 2012:60). Menurut Sujarweni (2015:39) perlakuan akuntansi terhadap sisa bahan adalah sebagai berikut: (1) Hasil dari penjualan sisa bahan dapat digunakan sebagai pengurangan biaya bahan baku yang digunakan dalam pesanan tersebut. (2) Hasil dari penjualan sisa bahan juga dapat diperlakukan sebagai pengurang pada biaya overhead pabrik. (3) Hasil dari penjualan sisa bahan selain diperlukan untuk pengurangan biaya bahan baku dan overhead pabrik juga diperlukan sebagai penghasil dari luar usaha (other income).

Bahan sisa yang ada pada PTPN I unit PKS Tanjung Seumantoh Aceh Tamiang yang merupakan produk sampingan dari hasil proses produk utama, terdapat 2 bahan sisa pada PTPN I unit PKS Tanjung Seumantoh Aceh Tamiang dimana bahan sisa tersebut di proses dari butiran biji kelapa sawit diolah menjadi $\mathrm{CPO}$, dari proses pengolahan $\mathrm{CPO}$ tersebut menghasilkan sisa bahan baku berupa cangkang sawit dan fibre.

Perlakuan terhadap pendapatan penjualan bahan sisa pada PTPN I unit PKS Tanjung Seumantoh Aceh Tamiang adalah sebagai pendapatan diluar usaha (other income) yang dicatat pada rekening pendapatan penjualan bahan sisa dalam kelompok penghasilan luar usaha (other income) dan ditutup kerekening laba rugi pada akhir periode akuntansi.

Perlakuan akuntansi untuk pencatatan cangkang sawit sebagai bahan sisa terlihat pada jurnal berikut.

$\begin{array}{llll}\text { Tahun 2016 } & \text { Kas } \quad 3.980 .907 .300 & \\ & \begin{array}{l}\text { Penjualan } \\ \text { 3.980.907.300 }\end{array} & \text { Sisa } & \text { Bahan }\end{array}$

$\begin{array}{llrl}\text { Tahun 2017 } & \text { Kas } & 2.911 .282 .410 & \\ & \text { Penjualan } & \text { Sisa } & \text { Bahan }\end{array}$

2.911.282.410

$\underline{\text { Tahun } 2018 \quad \text { Kas } \quad 2.328 .001 .120}$

Penjualan Sisa Bahan

2.328.001.120

Pada jurnal di atas, dapat dilihat bahwa perusahaan telah memenuhi perlakuan akuntansi terhadap sisa bahan dengan mengakuinya sebagai penghasilan di luar usaha (other income), sehingga pendapatan atas penjualan cangkang sawit disajikan pada laporan laba rugi perusahaan sebagai pendapatan lainnya yang menambah penghasilan utama dari penjualan CPO (Crude Palm Oil).

Oleh karena itu perusahaan menjual bahan sisa berupa cangkang dengan harga yang berbeda setiap 
bulannya. Pada tahun 2016 perusahaan menjual

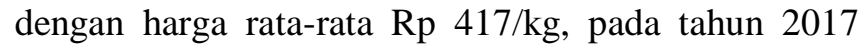
dijual dengan harga rata-rata $\mathrm{Rp} 413 / \mathrm{kg}$ dan pada tahun 2018 dengan harga rata-rata Rp 447/kg. perusahaan melakukan hal tersebut dengan tujuan untuk mengurangi kerugian yang mungkin diterima.

Berdasarkan hasil penelitian yang dilakukan, maka perlakuan akuntansi untuk sisa bahan baku cangkang pada proses produksi CPO diakui sebagai pendapatan diluar usaha (other income) oleh PTPN 1 unit PKS Tanjung Seumantoh Aceh Tamiang. Sedangkan perlakuan akuntansi untuk sisa bahan fibre dilaporkan pada laporan produk sampingan dan sisa bahan baku fibre digunakan untuk bahan bakar Boiler.

\section{Kesimpulan, keterbatasan dan saran \\ Kesimpulan}

Dari hasil penelitian yang dilakukan, maka dapat ditarik kesimpulan sebagai berikut:

1. PTPN I unit PKS Tanjung Seumantoh Aceh Tamiang memproduksi minyak kelapa sawit dimana dalam proses produksinya menghasilkan sisa bahan baku berupa cangkang sawit dan fibre.

2. Perlakuan akuntansi untuk sisa bahan baku cangkang sawit diakui sebagai pendapatan diluar usaha (other income) dan disajikan dalam laporan laba rugi perusahaan .

3. Sisa bahan baku fibre digunakan untuk bahan bakar Boiler dan pengurang biaya overhead pabrik.

\section{Keterbatasan penelitian}

Peneliti tidak memperoleh daftar harga fibre dari kantor Dewan Direksi bagian komersil perusahaan PTPN I karena sisa bahan baku berupa fibre sudah digunakan sepenuhnya untuk bahan bakar boiler di unit PKS tanjung Seumantoh Aceh Tamiang.

\section{Saran}

Saran praktis yang dapat saya berikan oleh peneliti antara lain:

1. Perusahaan sebaiknya melakukan penjurnalan terkait persediaan sisa bahan baku berupa fibre sebagai bahan bakar untuk boiler.

2. PTPN I unit PKS Tanjung Seumantoh Aceh Tamiang sebaiknya memperhatikan secara teliti bagaimana perlakuan akuntansi untuk sisa bahan baku.

\section{Daftar Pustaka}

Blocher, Stout D. E., \& Cokins, G. 2011. Manajemen Biaya Penekanan Strategi Buku 1 Edisi 5. Jakarta: Salemba Empat.

Bustami, B., \& Nurlela. 2013. Akuntansi Biaya Edisi 4. Jakarta: Mitra Wacana Media.

Carter, William K. 2009. Akuntansi Biaya. Salemba Empat. Jakarta.

Cecily A. Raiborn dan Michael R. Kinney. 2011. Akuntansi Biaya Dasar dan Perkembangan. Jakarta: Salemba Empat.

Ellystina, S. 2004. Analisis Hubungan Perlakuan Hasil Penjualan Sisa Bahan Terhadap Harga Pokok Produksi Studi Kasus pada Perusahaan Garmen PT. X.Thesis (Diploma) Tidak Dipublikasika. Bandung: Universitas Komputer Indonesia.

Halim, Abdul. 2012. Dasar-dasar Akuntansi Biaya Edisi 4. Yogyakarta: BPEF.

Indrawati. 2015. Metode Penelitian Manajemen dan Bisnis Konvergensi Teknologi Komunikasi dan Informasi.Bandung: Aditama.

Sekaran, U., \& Bougie, R. 2013. Research Methods for Business: A skill Building Approach. Edisi 5. New York: John wiley.

Sugiyono. 2013. Metode Penelitian Pendidikan Pendekata Kuantitatif, Kualitatif, dan $R \& D$. Bandung: Alfabeta.

Sujarweni, V. Wiratna. 2015. Metodologi Penelitian Bisnis \& Ekonomi. Yogyakarta: Pustakabarupress.

Susetya, F. C. 2001. Analisis Pengambilan Keputusan Penggunaan Sisa Bahan Dan Pengaruhnya Terhadap Harga Pokok Produksi (Studi Kasus Pada Perusahaan Roy Ventino Semarang. Thesis yang tidak dipublikasikan. Semarangan: Fakultas Ekonomi Universitas Katolik Soegijapranata 